БОРИСЛАВА ВУЧКОВИЋ

\title{
Београд
}

DOI 10.5937/kultura1546182V

УДК 392.81(=163.41)(497.5)

3316.723(=163.41)(497.5)

оригиналан научни рад

\section{ПТРАЗНИЧНА ТРПЕЗА}

Сажетак: Истраживање празничне трпезе једне руралне микрозаједнице у периоду соиијалистичке Југославије показује како формалним јеловником група потврђује и редефинише своје постојаюе. Јеловник је родно мушки обиљежен, али и по укусу свих конзумената. Обиље меса у оброчима показује да је пожељно класно тијело снажно (мушко) тијело, које открива најдубље диспозиције хабитуса. Алкохолна пића пију и мушкарции и жене, али мушкарци виме јер као припадничи доминантног пола имају већу потребу у репродуковању норме културе. Посао припремања и служења хране за столом није подвргнут ритуалним правилима и родно је женски обиљежен. Уношеьем промјена у јеловник и еманципацијом жене за трпезом, ова патријархална микрозаједница показује динамичност и флексибилност, чиме се негира стереотип о пасивности сеоског становниттва. Разлике у економској моћи најмање су видљиве на празничној трпези, ито потврђује Бурдијеову (Bоurdieu) тезу да је храна повлаштена област гдје је симболички могуће повратити дигнитет и самопоштоване друштвених група које реално, економски и сочијално стоје на дну друштвене љествице.

Кључне ријечи: храна, пиће, празник, рурална микрозаједница

Култура се не односи само на узвишене производе људског духа, већ на све могуће облике испољавања и представљања различитих друштвених група и појединаца, али и открића да храна представља камен-темељац сваке културе. ${ }^{1}$ Избор хране, њена класификација, начин на који се прибавља, спрема, сервира и конзумира су културна појава која представља својеврсно огледало разних аспеката друштвено-културног ентитета чији дио представља (привредни, економски, религијски итд.). ${ }^{2}$ Иако су избори хране на неки начин у вези с расположивошћу, људи никад не једу сваку

1 Đorđević, J. (2005) Hrana: interpretacije i inovacije, Kultura br. 109-112, I knjiga, Beograd: Zavod za proučavanje kulturnog razvitka, str. 15.

2 Костић, С. Ђ. Окрепљење тела, у: Приватни живот код Срба у деветнаестом веку: од краја осамнаестог века до почетка Првог светског 
јестиву и доступну храну у својој околини. ${ }^{3}$ Њихове преференције у вези с храном близу су средишту њихове самодефиниције: за људе који једу примјетно различиту храну, или сличну храну на различите начине, мисли се да су битно другачији, понекад чак мање људи. Како се једе, чиме се једе и, наравно, шта се једе, говоре посматрачу много више него што изгледа на први поглед. ${ }^{4}$

У руралној микрозаједници Ђурчића на сјеверним обронцима планине Папук у Славонији у периоду социјалистичке Југославије, ${ }^{5}$ за крсну славу Ђурђево и празник Св. Саву припрема се храна и пиће током цијеле године, а количина овиси о броју позваних гостију и броју оброка који се приправљају. Крсна слава се слави два дана те се први дан припрема доручак, ручак и вечера, други дан доручак и ручак. Св. Сава се слави један дан и, пошто гости из других села долазе касније у току дана, не припрема се доручак, већ ручак и вечера. Додатна количина хране треба се спремити за Ђурђево зато што гости на одласку добијају „спремак” печеног меса и колача који носе својој кући, обичај који је познат и у другим срединама. ${ }^{6}$ Већа количина хране и пића која се мора припремити за Ђурђево, а коју диктира број оброка за трпезом, „спремак” и већи број гостију, дају већи „симболички капитал” крсној слави, коју у оквиру проширене приватности за породицу и домаћинство она има и када се на трпезу износи „све оно најбоље што се током године припремало и чувало у кући за славу”7. Како је, према Бурдијеовом (Bourdieu) мишљењу, у основи свих капитала економски капитал, на примјеру хране и пића који се

pama, приредили Столић, А. и Макуљевић, Н. (2006), Београд: Clio, стр. 385 .

3 Minc, S. (2005) Hrana, društvenost i šećer, Kultura бp. 109-112, I knjiga, Beograd: Zavod za proučavanje kulturnog razvitka, str. 283.

4 Чолак-Антић, Т. Један кратак поглед у књигу рецепата, у: Приватни живот код Срба у двадесетом веку, приредио Ристовић, М. (2007), Београд: Clio, стр. 363.

5 Претходно објављени радови исте ауторке у којима се истражују други микронаративи овог микроколектива могу се наћи и у Језик, књижевност и религија (приредили Александар Прњат и Тијана Парезановић) = Language, Literature and Religion (edited by Aleksandar Prnjat and Tijana Parezanović), Београд: Алфа универзитет = Alfa University, 2014, 38-54 (Религијски елементи у фотографским посмртним меморабилијама) и часопису Култура бр. 134, Београд: Завод за проучавање културног развитка, 2011, стр. 152-181 (Медијска култура Ђурчана).

6 Исић, М. Приватност на селу, у: Приватни живот код Срба у двадесетом веку приредио Ристовић, М. (2007), Београд: Clio, стр. 403.

7 Јовановић, Б. Крсна слава, у: Приватни живот код Срба у деветнаестом веку: од краја осамнаестог века до почетка Првог светског рата приредили Столић, А. и Макуљевић, Н. (2006), Београд: Clio, стр. 603. 
припремају за крсну славу и Св. Саву исказује се важност коју становници Ђурчића придају „симболичком капиталу” ради стицања друштвеног признања. У послијератном периоду, у вријеме највећег сиромаштва становника, слава се најскромније обиљежава, али и нешто касније се за славу „мора” имати и припремати, по цијену да се „послије славе осиромаши”, како свједочи једна моја саговорница. Премда су пред домаћинством додатни напори јер се Ђурђево и Св. Сава славе у непосно вријеме, ${ }^{8}$ разлике у економској моћи становника села најмање су видљиве на празничној трпези. Објашњење за овакав однос према храни дао је Бурдије показавши да је храна повлаштена област гдје је симболички могуће повратити дигнитет и самопоштовање друштвених група које реално, економски и социјално стоје на дну друштвене љествице. ${ }^{9}$ Пракса прослављања Ђурђева и Св. Саве у Ђурчићима показује да гости у кући на одласку добијају једну врсту поклона у храни, „спремак”, а не доносе поклоне, којима би се, како пише Бурдије, смањили трошкови домаћина у име једне реалистичке представе о трошковима оброка и воље да се учествује у њиховом смањењу. ${ }^{10}$ Гостопримство које се гостима пружа за трпезом има значајну друштвену компоненту, којом се потврђује мрежа односа путем ритуалне размјене посјета. ${ }^{11}$ Они који су данас домаћини у Ђурчићима, сутра ће бити гости, за крсну славу или другу врсту славља у другом селу или мјесту, и јеловник ће бити исти као у домаћинској кући, а за крсну славу ће се и у гостима добити „спремак”. Обрасци угошћавања за трпезом и „спремак” за крсну славу припада истом „рукопису”12 чланова различитих сеоских група које имају сличне стилове живота, који су производи хабитуса. Хабитус је оно што чини да су све праксе једног агенса (или групе агенса који су производ сличних услова) истовремено систематичне утолико што су оне производ истовјетних (или међусобно замјенљивих) образаца, и систематски различите од пракси које чине неки други стил живота. Тако су стилови живота систематски производи хабитуса који постају системи друштвено квалификованих знакова (нпр. „отмјен”, „прост” итд.). Све праксе и сва дјела једног агенса су усклађена

8 Prošić-Dvornić, M. (2005) Kulturni i društveni značaj hrane u tradicionalnoj srpskoj kulturi, Kultura br. 109-112, II knjiga, Beograd: Zavod za proučavanje kulturnog razvitka, str. 330-331.

9 Đorđević, J. nav. delo, str. 30.

10 Burdije, P. (2005) Habitus i prostor stilova života, Kultura br. 109-112, I knjiga, Beograd: Zavod za proučavanje kulturnog razvitka, str. 162.

11 Prošić-Dvornić, M. (2006) Odevanje u Beogradu u XIX i početkom XX veka, Beograd, Stubovi kulture, str. 190-192.

12 Burdije, P. nav. delo, str. 134. 
међу собом, мимо сваке намјерне потраге за кохеренцијом, и објективно усаглашена, мимо сваког свјесног договора, с праксама и дјелима свих чланова исте класе. Праксе једног истог агенса и, уопште, праксе свих агенса једне исте класе, дугују „стилску сличност” која чини сваку од њих метафором било које друге, чињеници да су оне производ трансфера истих образаца дјеловања с једног поља на друго.

Асортиман производње истовремено детерминише и избор јестивих намирница у исхрани, а културна правила прописују структуру оброка и начин конзумирања хране. ${ }^{13}$ При томе, оброк је висококонструисан културни и друштвени догађај и храна, као саставни дио ритуала, има свој удио у организацији друштвеног времена. Како се ови празници у Ђурчићима славе у непосно вријеме, према стандардизованом „мрсном”14 јеловнику за сваки оброк на трпезу се сукцесивно износе слиједећа јела и пића:

„РУЧАК” ${ }^{15}$, тј. доручак, који се припрема само за Ђурђево:

кувана ракија, паче ${ }^{16}$ и домаћи „крув”, дроб (пржена свињска цријева), ћелап (пржено свињско месо на луку) и домаћи „крув”;

„УЖНА” (ужина), тј. ручак, и ВЕЧЕРА:

ракија, кокошја супа, кокошје кувано месо, хрен и домаћи „крув”; 1950-их се почиње служити и сос од парадајза, сарма са сувим месом и домаћи „крув”, свињско печење, ${ }^{17}$ јагњеће печење, салата (кисела паприка, кисели купус, паприка која се кисели у киселом купусу) и домаћи „крув”, „дебели колачи” с маком и орасима; касније се почињу правити „слатки” колачи (ситни колачи, ролати, торте и слично).

Од пића: ракија, вино, касније индустријско пиво и сокови, кафа.

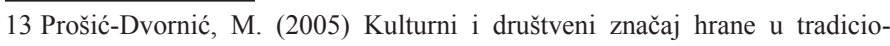
nalnoj srpskoj kulturi, Kultura бp. 109-112, II knjiga, Beograd: Zavod za proučavanje kulturnog razvitka, str. 322-323.

14 Исић, М. нав. дело, стр. 403: За „мрсно” прослављање аутор наглашава да трошкови нису безначајни.

15 Prošić-Dvornić, M. (2006) Odevanje u Beogradu u XIX i početkom XX veka, Beograd: Stubovi kulture, str. 214. Другачији називи оброка од данас раширених помиње у вези с београдском средином и ова ауторка: вечере се називају ручком, а ручак доручком.

16 Пихтије.

17 Костић, С. Ђ. нав. дело, стр. 389. Печено прасе се служи при особитим приликама. 
У свакој кући се у исто вријеме служи доручак, ручак и вечера, и према истом прописаном јеловнику сукцесивно износе јела према „руском моделу”" једног хабитуса реда, држања и суздржавања од којег се не може одустати, ${ }^{19}$ што се односи и на вријеме оброка. Ако се овим правилима везаним за избор јела и начин служења дода и распоред активности да се послије ручка и вечере иде „У игру” гдје се игра и пјева, све то указују да ове гозбе нису „карневалског карактера" 20 , посебно „карактеристичне за римокатоличке средине"21.

Правила за припремање хране у Ђурчићима нису подвргнута скупу строгих ритуалних правила која се морају слиједити. ${ }^{22}$ Ако је у домаћинству више жена, онда „крув” мијеси и пече газдарица. Она ту улогу у вишечланом домаћинству стиче преузимајући је када је и сама старија, што значи да се рецепт преноси усменом комуникацијом. У изузетним ситуацијама, на примјер у газдаричиној одсутности, у вишепородичном домаћинству „крув” може мијесити и пећи млађа жена. Ако се ради о модерној породици, састављеној од родитеља и дјеце, онда жена увијек мијеси и пече „крув”, чиме модернизацијски процес смањења броја чланова домаћинства изравно утиче на изостанак ритуалних правила у вези с припремањем хране. Начин припремања ове намирнице остаје исти током читавог периода, што значи да и процес комуникације међу домаћицама остаје исти, те на њега не утичу медији попут штампе и телевизије, ${ }^{23}$ као ни нови тип електричног штедњака који је премали за припрему потребне количине хране („крува”, печења, „дебелих колача”). Иако не постоје ритуална правила за припремање „крува”, са̂м посао је родно обиљежен и обављају га само жене. Премда се „крув” за Св. Саву и Ђурђево не прави од неког посебног брашна, житно брашно у послијератном периоду ипак има ритуалну важност. Наиме, ако домаћинство нема довољно жита за „крув” за цијелу годину, онда се прави „смјеса” од жита и кукуруза, која се послије меље у млину. Међутим,

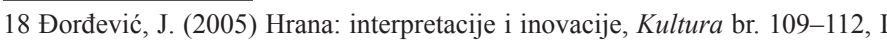
knjiga, Beograd: Zavod za proučavanje kulturnog razvitka, str. 28.

19 Burdije, P. nav. delo, str. 160.

20 Đorđević, J. nav. delo, str. 52.

21 Prošić-Dvornić, M. (2006) Odevanje u Beogradu u XIX i početkom XX veka, Beograd: Stubovi kulture, str. 186.

22 Prošić-Dvornić, M. (2005) Kulturni i društveni značaj hrane u tradicionalnoj srpskoj kulturi, Kultura br. 109-112, II knjiga, Beograd: Zavod za proučavanje kulturnog razvitka, str. 333.

23 Gudi, Dž. (2005) Gore i dole: kulinarska kultura Azije i Evrope, Kultura br. 109-112, I knjiga, Beograd: Zavod za proučavanje kulturnog razvitka, str.. 112. 
„крув” за ове празнике се припрема само од квалитетнијег житног брашна. Уз то, за крсну славу се не припрема славски колач, већ „славски крув”, визуелно означен утискивањем знакова на тијесто. Тиме домаћи „крув” припремљен за ове празнике, а посебно за Ђурђево, постаје храна која утемељује идентитет: лични, породични, колективни.

Да је припремање хране родно обиљежено, показују кувана јела у јеловнику. Бурдије склоност ка куваним јелима, која захтијевају велико улагање времена и пажње, повезује с традиционалним схватањем женске улоге. ${ }^{24}$ Кување је „нижи” начин спремања хране који захтијева доста времена. Није случајност што је та кухиња, пише он, симбол одређеног женског положаја и подјеле рада између полова. За разлику од положаја жене у градском домаћинству, положај жене у сеоском домаћинству му нимало не сличи. ${ }^{25}$ У селу су жене обављале пољске радове готово равноправно с мушкарцима, тако да се нису могле пуно посветити спремању јела. Жене у граду нису имале других послова осим кућних, тако да су биле у прилици да проводе добар дио дана у кухињи бринући се да храна буде по укусу укућана. Занимљиво је да Чолак-Антић наводи како се у селу сарме и пуњене паприке нису завијале и пуниле све до између два свјетска рата, jep су захтијевале пуно времена и труда за припремање, а поред тога неопходни састојци су рижа, која је била скупа, и месо. Знамо да се у Ђурчићима сарма спремала и прије Другог свјетског рата, те се обичај наставио и касније. Из антрополошког угла, „,кувати” намирнице значи потчинити их конвенционалним нормама; преобразити их из Природне хране (опасне „сирове”) у Културну (,правила на снази”). ${ }^{26}$ Храна ће, пише Фишле, обрађена по пропису, покорно пронаћи пут до свог мјеста на тањиру; истовремено, она ће убиљежити свој коิд у општи поредак свијета и послужити као потврда о континуитету и опстанку тог и таквог поретка.

Оброци састављени од двије или три врсте јела, какви су у Ђурчићима за Св. Саву и крсну славу, Сидни Минц (Sidney Mintz) сматра европском навиком. ${ }^{27}$ Он пише да се преференције у вези с храном јављају рано у животу и настају у

24 Burdije, P. (2005) Habitus i prostor stilova života, Kultura br. 109-112, I knjiga, Beograd: Zavod za proučavanje kulturnog razvitka, str. 150.

25 Чолак-Антић, Т. Један кратак поглед у књигу рецепата, у: Приватни живот код Срба у двадесетом веку, приредио Ристовић, М. (2007), Београд: Clio, стр. 366.

26 Fišle, K. (2005) Funkcije ishrane, Kultura br. 109-112, I knjiga, Beograd: Zavod za proučavanje kulturnog razvitka, str. 198.

27 Minc, S. (2005) Hrana, društvenost i šećer, Kultura br. 109-112, I knjiga, Beograd: Zavod za proučavanje kulturnog razvitka, str. 294. 
оквирима које постављају они који хране, дакле, у оквирима правила њиховог друштва и културе. Отуд исхрана и укуси имају огроман афективни набој. Шта волимо, шта једемо, како то једемо и како се у вези с тим осјећамо, феноменолошки су међусобно повезане ствари; заједно, јасно одговарају на питање како видимо себе у односу на друге. Унакрснокултурна истраживања преференција у исхрани, пише он, јасно показују да су универзуми које људске групе узимају здраво за готово као своју „природну средину” очито друштвени, симболички конструисани универзуми. Шта представља „добру храну”, као и шта представља добро вријеме, доброг брачног друга или испуњен живот, друштвена је а не биолошка ствар. Пјер Бурдије је показао да опредјељење за одређену врсту исхране у модерном друштву не зависи од мјеста у класном поретку у ужем смислу, већ од „укуса” (социолошка и естетска категорија) који се у оквиру, али и мимо тог поретка гради. ${ }^{28}$ Укус као социолошка категорија гради се у међусобном динамичком односу објективне класне припадности, статуса одређене друштвене групе, који зависи и од „културног капитала”, стила живота у који је као значајан фактор укључена перцепција тијела и ефеката које храна има за живот и изглед тијела у оквиру сваке класе. ${ }^{29}$ Укус не зависи од урођених преференција, већ је дубоко друштвено условљен и у великој мјери зависи од слике коју друштвена класа има о себи, у односу на друге класе. Бурдије тако укида категорију естетског, иначе везану за појам укуса, али и приоритет економског фактора за изградњу стила живота одређене класе.

О естетској страни хране ипак се може говорити, јер се у Ђурчићима она изражава у припреми трпезе за Ђурђево и Св. Саву. На трпезу се ставља свечани бијели столњак, домаћи ткани украшен мавезом, а касније и дамастни.

Иако је храна која се припрема у Ђурчићима за ове празнике разноврсна и у њој има различитих укуса (слано, љуто, кисело, слатко), којој се придружују и пића различитог укуса (горко, кисело, слатко), двије намирнице доминирају јеловником. То су месо (паче, дроб, ћелап, супа, кокошје кувано месо, сарма, печење) - „намирница за имућније” и „крув”„сиротињска храна или храна за сиромашне”зо.

Идеју да је месо најважнији елемент људске исхране заступали су многи европски историчари, што се добро слаже с

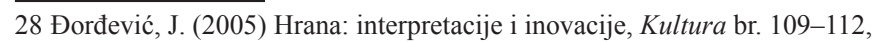
I knjiga, Beograd: Zavod za proučavanje kulturnog razvitka, str. 29.

29 Исто, стр. 29.

30 Исто, стр. 31. 
вриједностима које су у прошлости практиковали богати, а сиромашни сматрали идеалом. ${ }^{31}$ Ова намирница иначе има велики удио у јеловнику европске кухиње за разлику од ваневропских, ${ }^{32}$ и управо буржоаски модел (месо за сваки оброк, а сваки оброк се састоји од предјела, јела с месом, поврћа, сира и десерта) настоји да се наметне и хомогенизује навике Европљана за столом. ${ }^{33}$ Месо припремљено кувањем, печењем и пржењем служи се у Ђурчићима у сва три оброка на свечаној трпези. И док су сва три јела за доручак направљена од меса, међу којима мислим да ћелап представља зенит оброка, врхунац или главно јело ручка и вечере је печење. То је јело којем се полако прилази од уводне супе, преко куваног меса и омиљене сарме. Посебну вриједност међу печењем заузима јагњеће. Свакодневни оброци у Ђурчићима, посебно у послијератном периоду, не обилују месом, тако да је његово обиље карактеристично управо за празнике који се одржавају у непосно вријеме. Давање предности тешкој храни, масној и јакој, чија је парадигма свињетина, масна и сла(с)на, као антитеза риби, немасној, лакој и благог укуса, Бурдије повезује с тим што се у храни тражи њена бит хранљиве материје, која се „хвата” за тијело и која даје снагу. ${ }^{34}$ Друштвена дефиниција одговарајуће хране, сматра Бурдије, не утврђује се само посредством квазисвјесне представе о прихваћеној норми опажене тјелесне грађе, посебно у случају дебљине или виткости. У дубљем смислу, у основи избора појединих намирница стоји читава тјелесна схема, а нарочито држање тијела за вријеме јела. Бурдије пише да мушком идентитету одговара - храна која се „хвата” за тијело, није „пипава” за јело, која се једе на мушки начин, а не суздржано, и то у великим залогајима, својски снажним жвакањем свим зубима, у крупним залогајима, како доликује мушкарцима и то у количинама које су веће у односу на оне које једу жене. Практична филозофија мушког тијела, пише аутор, као нека врста „силе”, велика, снажна, с огромним, неодољивим и животињским потребама, која се показује у читавом мушком начину држања тијела, посебно пред храном, такође стоји у основи подјеле хране на „мушку” и ,женску”, подјелу коју, како у праксама тако и у дискурсима, прихватају оба пола. На мушкарцима је да једу више, и то јачу храну, као што су и они јаки. Мушко

31 Gudi, Dž. (2005) Gore i dole: kulinarska kultura Azije i Evrope, Kultura br. 109-112, I knjiga, Beograd: Zavod za proučavanje kulturnog razvitka, str. 74.

32 Исто, стр. 74: Гуди наводи примјер да Кинези нису као многе индијске групе месо одбацили из духовних разлога; једноставно га није било довољно,

33 Đorđević, J. nav. delo, str. 31.

34 Burdije, P. nav. delo, str. 163. 
јело је месо, хранљива намирница по превасходству, која је јака и даје снагу, која окријепљује, која је добра за „крв” и за здравље - мушкарцима месо сљедује по дефиницији. За разлику од закључка до којега Бурдије долази у својој анализи да женама мушка храна није „по укусу” и сматра се чак и штетном ако је уносе у већим количинама, па тако може изазвати и неку врсту гађења, у овој микрозаједници месо је и женама по укусу, не сматрају га штетним ако га уносе у већим количинама, а нема ни говора да изазива било какву врсту гађења. Стога је јеловник празничне трпезе у Ђурчићима родно обиљежен, мушки, али је по укусу свих конзумената, без обзира на полне разлике.

Обиље меса у оброцима показује и какво је пожељно „класно тијело". Бурдије пише да видљива тјелесна грађа открива најдубље диспозиције хабитуса. ${ }^{35}$ Када је у питању храна, овај аутор сматра да укус зависи и од идеје коју свака класа има о тијелу и о ефектима хране на тијело, односно на његову снагу, његово здравље и његову љепоту, као и од категорија које користи да оцијени те ефекте, будући да једна класа може обраћати пажњу на неки од њих, док га друга класа сасвим занемарује, и да различите класе различито хијерархијски распоређују различите ефекте. Аутор објашњава да шири слојеви више воде рачуна о „снази” (мушког) тијела него о његовом „облику”. Теза је потпуно примјенљива у овој микрозаједници, посебно током првих деценија истраживаног периода, али не само за мушко, него и за женско тијело. Наравно да Ђурчани користе описне придјеве за дебљину, али шта у једној заједници значи бити дебео? За крупног мушкарца се у Ђурчићима каже да је ,jак”, дјевојчица/дјечак је ,,јака/јак”. Жена такође може бити ,jака”, али за њу постоји још један придјев, а то је „честа” (честита). „Ограничени код” или „код интимности”з6 омогућује његовим корисницима разликовање крупног и дебелог „класног тијела" ${ }^{37}$ према сопственим критеријумима, које би у савременом друштву „обневиделом од бављења телесним здрављем”з8 његови припадници сигурно „видјели” као „дебело”.

Месо које се треба пећи, посао који такође обављају жене, реже се, ставља у велике тепсије и затим у врућу „крушну пећ”. Ова циглом узидана пећ се налази у дворишту готово

\section{5 Исто, стр. 152.}

36 Bernstajn, B. (1979) Jezik i društvene klase, Beograd, BIGZ, str. 19-186.

37 Burdije, P. nav. delo, str. 152.

38 Furnije, D. (2005) Fermenti kultura, Kultura br. 109-112, I knjiga, Beograd: Zavod za proučavanje kulturnog razvitka, str. 302. 
сваке куће у селу све до 1991. године. У њој се ложи ватра, потом се жар уклања да би се унијело оно што треба испећи, па се то пече док се пећ хлади. И послије увођења електричне енергије у село и куповине електричних штедњака користи се крушна пећ, јер су модерне рерне мале да би се у њима пекле велике количине меса какве се припремају за ове празнике.

Иако се у крушној пећи пеку месо, „дебели колачи” и „крув”, придјев крушни у вези је с крушним или флокеним брашном, ${ }^{39}$ што значи да је основна намјена ове пећи печење „крува”. Постојање крушне пећи као одвојене цјелине у дворишту материјални је доказ да становници овога села припадају „скробној култури”40 и важности коју ова намирница има у свакодневној исхрани. То потврђује и обиље меса, али само у празничном јеловнику. Повећање економског капитала током деценија није измијенио навику становника да једу „крув” у сваком свакодневном и празничном оброку, а не треба занемарити да ове пећи постоје и употребљавају се све до 1991, што такође потврђује тезу о скробној култури.

Сидни Минц сматра да је већина великих (или много мањих) седентарних цивилизација изграђена на гајењу одређеног сложеног угљеног хидрата, као што је кукуруз, кромпир, рижа, просо или жито. ${ }^{41}$ У овим, на скробу заснованим друштвима, обично али не увијек хортикултурним или агрикултурним, људи се хране тако што њихово тијело прерађује сложене угљене хидрате, зрнасте или кртоласте, у тјелесне шећере. Остале биљке, уља, месо, риба, живина, воће, коштунице и зачини - многе од њих нутритивно неопходни састојци - такође се једу, али их сами корисници обично сматрају секундарним, макар и неопходним, додацима основном скробу. То уклапање основног, сложеног угљеног хидрата и додатака за укус је фундаментална одлика људске исхране. Навике народа који једу хлеб и користе масноће и со да би дали укус великим количинама хлеба које обично једу, пише Минц, такође су општепозната. ${ }^{42}$

39 „Крув” праве искључиво жене од крушног или флокеног брашна добијеног од самљевеног жита које се мљело у воденици на камен. Ово воденичарско брашно, у којем су и мекиње, мора се просијати да би се одвојиле посије, тј. отпадак од просијаног крушног брашна. Жене просијавају овакво брашно како би добиле чисто брашно. У познијем периоду Ђурчани мијењају своје жито за брашно. Жене судјелују и у производњи жита, што доказују и фотографије с вршидбе жита у Ђурчићима.

40 Minc, S. (2005) Hrana, društvenost i šećer, Kultura br. 109-112, I knjiga, Beograd: Zavod za proučavanje kulturnog razvitka, str. 292.

41 Исто.

42 Исто, стр. 295. 
Да се сложени угљени хидрати налазе у основи исхране у Ђурчићима јасно је, као и то да долази до промјена и уношења једноставних угљених хидрата. Пријелазна храна која je примјер комбинације једноставних и сложених угљених хидрата су „дебели колачи”, који се праве од брашна, али којима се додаје индустријски обрађени шећер. Произведени шећери као што су сахароза, декстроза и фруктоза, који се технохемијски производе и рафинишу, морају се разликовати од шећера какви постоје у природи. ${ }^{43}$ Управо индустријски произведени шећер постаје значајан састојак „слатких колача" (ситни колачи, ролати, торте) који временом улазе у јеловник за крсну славу и Св. Саву у Ђурчићима. Минцова теза да је значај слатког међу преференцијалним укусима временом растао (и да није био карактеристичан прије XVIII вијека) потврђује се и на микронивоу у Ђурчићима, jep се количина и врста припремљених колача повећава, на шта утиче не само повећање економског капитала становника, него и значај и удио слатког у празничном јеловнику. Иако данас на Западу културолози (а можда и већина научника), пише овај аутор, слатко сматрају квалитетом супротним горком, киселом и сланом, слатки укуси имају повлаштен положај у односу на знатно варијабилније ставове према киселим, сланим и горким укусима, што не искључује заједничке склоности према одређеним киселим, сланим или горким супстанцама. Количина и квалитет врста колача постају и питање престижа, „културног капитала”, али генерацијски условљено, јер нове врсте припремају млађе домаћице, као и оне које не живе у селу, али доносе их, на примјер, у своју родитељску кућу. Старије жене углавном праве „дебеле колаче”, док неке млађе праве и „слатке колаче”, размјењујући рецепте с комшиницама, пријатељицама, рођакама, задржавајући усмени начин комуникације. Појављују се и биљежнице у које домаћице записују рецепте. Ипак, и поред повећања улоге слатког у јеловнику, у њему све вријеме доминира слано. Колачи се никада не износе за доручак, а слатко долази на ред послије свих осталих јела, тј. на крају оброка (ручка и вечере), што доказује доминантну позицију сланих јела. Ако је слатко постало преференцијални укус на Западу, у свечаном јеловнику за Ђурђево и Св. Саву оно то у Ђурчићима није постало.

Пића заузимају посебно мјесто у систему исхране: више него било која друга намирница, неопходна су организму. ${ }^{44}$ Поред симболичког богатства, због тога што се посматрају производом тежње ка хедонизму, као „мазиво” друштвених

43 Исто, стр. 300.

44 Furnije, D. nav. delo, str. 302. 
односа, пиће отвара проблем размјене између индивидуалног и колективног. Зато није чудно што управо пићем, ракијом или куваном ракијом, у Ђурчићима почиње свечаност за трпезом, чиме алкохол прије свега врши „социо-интегративну функцију"45. Клод Фишле пише да алкохол представља нешто потпуно посебно и суштински другачије у односу на храну јер утиче на понашање и психу човјека, додуше привремено али веома реално и, прије свега, готово истог часа након конзумације. Његова социјална функција је амбивалентна, управо због тога што су и сами ефекти које производи амбивалентни. Пиће омогућава симболичну интеграцију у групу, ојачава социјабилност и креира социјалну ситуацију и интегративни је фактор јер привремено уклања формалне препреке. Без обзира да ли је ријеч о великим пријемима или забавама, пише Фишле, чаша заузима увијек значајније мјесто од тањира, чиме се помоћу алкохолних пића ослобађа простор за интимност и за комуникацију, било да се ради о дионизијским свечаностима или о интимним вечерама.

Већина домаћинстава у Ђурчићима производи ракију и вино, пошто у приватном власништву имају своје шљивике и винограде. Ипак, послије Другог свјетског рата мало ко има довољно грожђа, јер су шљивике уништиле бомбе њемачких авиона. Током рата уништени економски капитал становника утиче на производњу пића, што изискује додатне издатке за његово набављање. Тако, на примјер, Ђурчани купују вино и у Буквику, несрпском селу које се налази између Ораховице и Кокоћака. Довољне количине ракије становници ће имати тек када нове воћке које су засадили почну доносити плодове. Поред вина и ракије, која је „симбол културе”46 за Ђурчане, негдје од седамдесетих година XX вијека почињу се куповати индустријско пиво и сокови.

Алкохолна пића у Ђурчићима пију и мушкарци и жене, с тим што мушкарци пију веће количине. Да жене пију алкохолна пића, на примјер ракију, није необично, јер су се ове опасне калорије некада сматрале „неопходним за физички рад" ${ }^{47}$. Доминик Фурније (Dominique Fournier) сматра да пића која собом носе потенцијални неред друштво поставља у чврсте оквире колективног живота, јер се једино тако човјек може упрегнути у јарам установљених норми. Једна од норми у Ђурчићима је да се ракија сипа у мале чаше.

45 Fišle, K. (2005) Funkcije ishrane, Kultura бp. 109-112, I knjiga, Beograd: Zavod za proučavanje kulturnog razvitka, str. 203.

46 Furnije, D. nav. delo, str. 311.

47 Исто, стр. 304. 
Фурније супротставља културне навике на ферментисана пића, која имају нутритивну вриједност и представљају облик комуникације традиционално везиваних за вина од грожђа или палме, и свих других пића која су некада била дио наднице за физички рад на афричким, америчким и медитеранским пољима, флашираним пићима, у чему шећер није ферментисао. ${ }^{48}$ Таква пића су индустријско пиво и сокови. Посљедњи су генерацијски и родно обиљежени јер их у Ђурчићима пију дјеца и жене, чиме мушкарци као „доминантни пол има(ју) много већу потребу да репродукују норме једне културе него да једноставно конзумира(ју) какво опојно пиће"49. То потврђује чињеница да су управо они ти који пију пиво. Стога не чуди да је и пијанство за вријеме ових великих празника у Ђурчићима за мушки пол друштвено прихватљиво, за разлику од женског пола, као и чињеница да никада није било ексцесних ситуација, што значи да постоји контрола пијанства и од стране појединца и од стране групе.

Послије Другог свјетског рата, када је село спаљено и имовина уништена, у почетку се користе алуминијски тањири и прибор за јело (кашике, виљушке, ножеви) и земљане здјеле. Касније их замјењују лименим тањирима, послије којих долазе керамички, које у Ђурчићима називају „порцулански”. Занимљиво је да у овом селу употреба индивидуалног прибора за јело, што се сматра одразом нове индивидуалности, ${ }^{50}$ уз промјене у односу на квалитет материјала, није ишла у правцу повећања броја тањира, па се до 1991. године сва јела једу из једног дубоког тањира. И просторни распоред за трпезом послије рата се мијења, пошто су раније жене и мушкарци сједили на супротним странама стола. „Ритуализација друштвеног реда"51, која има функцију његовог потврђивања и учвршћивања, мијења се и у вези с мјестом домаћице за трпезом за вријеме јела. Она послужује јело и у вријеме празника и свакодневно, али послије рата она једе за трпезом. Када је Српкиња сјела за сто да једе с мужем, а

48 Исто, стр. 305: У вријеме када мултинационалне компаније контролишу тржиште пића и жеђ натјера човјека да попије нешто флаширано, објашњава Фурније, вјешто одмјерен додатак $\mathrm{CO} 2$ ствара илузију онаквог живота за какав су до скора била задужена ферментисана пића.

49 Исто.

50 Тимотијевић, М. (2006) Рађање модерне приватности: приватни живот Срба у Хабзбурикој монархији од краја 17. до почетка 19. века, Београд: Clio, стр. 207.

51 Prošić-Dvornić, M. (2006) Odevanje u Beogradu u XIX i početkom XX veka, Beograd: Stubovi kulture, str. 122. 
није више стајала поред да би послуживала, био је то велики цивилизацијски скок у области исхране. ${ }^{52}$

Промјене у јеловнику у Ђурчићима су споре и одраз су повећања економске моћи становништва, као и тога да обичај припремања одређених врста јела освјежава јеловник. Мијењање јеловника увођењем нових јела потврђује Хобсбаумову (Hobsbawm) тезу да „обичај” у традиционалним друштвима до одређене тачке не спријечава иновацију и промјену, мада захтјев да „обичај” мора одговарати или бити идентичан с претходним обрасцима томе очигледно поставља чврсте границе. ${ }^{53}$ Ова комбинација суштинске флексибилности и формалне вјерности претходним примјерима видљива је у увођењу у јеловник соса од парадајза (педесетих година XX вијека), који се служи као додатак куваном месу, „слатких” колача и индустријског пива и сокова. Исте врсте јела и распоред служења за крсну славу Ђурђево и Св. Саву, уз мале новине, чине трпезу формалном и конзервативном. Џек Гуди (Jack Gudi) сматра да је однос према храни најконзервативнији аспект културе. ${ }^{54}$ Дијелом овај формализам и континуитет аутор објашњава тиме што су они посљедица учења непосредним искуством, у раном узрасту, код куће, у домаћем окружењу, те отуда и њихова велика моћ одржања. Релативни конзервативизам конкретних јела Гуди сматра да би могао бити одраз њихове релативне неповезаности с остатком друштвенокултурног система. Онда би аутономија неких аспеката кувања била та због које оно има посебну важност за појединце у временима друштвених промјена, поготову наглих, револуционарних. За сеоску заједницу један од важних узрока формализма и континуитета трпезе за Ђурђево и Св. Саву јесте то што је село „произвођач хране коју конзумира" 55 . Заправо, осим индустријског пива, вина, сокова и ограниченог броја зачина који се користе у Ђурчићима, већина хране се производи у селу, што значи да није дошло ни до временског нити просторног поремећаја у вези с производњом и потрошњом хране. Како је фундаментални услов свих промјена везаних за храну индустријализација

\footnotetext{
52 Чолак-Антић, Т. Један кратак поглед у књигу рецепата, у: Приватни живот код Срба у двадесетом веку, приредио Ристовић, М. (2007), Београд: Clio, стр. 364.

53 Hobsbom, E. Uvod: kako se tradicije izmišljaju, u: Izmišljanje tradicije priredili Hobsbom, E. i Rejndžer, T. (2002), Beograd: Biblioteka XX vek, str. 7.

54 Gudi, Dž. (2005) Gore i dole: kulinarska kultura Azije i Evrope, Kultura br. 109-112, I knjiga, Beograd: Zavod za proučavanje kulturnog razvitka, str. 128 .

55 Чолак-Антић, Т. нав. дело, стр. 365.
} 
хране ${ }^{56}$ јасније је зашто је свечана трпеза у овој микрозаједници формална.

Конзервативном трпезом за ове празнике „истинске традиције" група потврђује и редефинише своје постојање, исказује и потврђује лични, породични и колективни сеоски идентитет, те има важну религијску, друштвену и националну компоненту. Напор да се одржи једном успостављени друштвени ред свој појавни облик потврђује и у јеловнику. Управо кулинарски систем, као један од елемената културе, служи као упоришна тачка одређеног поретка. ${ }^{57}$ Модерно друштво, пише Јелена Ђорђевић, које руши границе кулинарских система растурајући их и на вертикалном и на хоризонталном нивоу, укида њихова регулативна својства што подстиче дубоки немир. И поред утицаја макродруштвених промјена у социјалистичкој држави које су се одразиле и на ову микрозаједницу, кулинарски систем Ђурчића за Ђурђево и Св. Саву се одржао од краја Другог свјетског рата до 1991 , чиме је означио и одржање дијела поретка.

Намирнице и припремање хране, кување, основа су осјећаја колективне припадности. ${ }^{58}$ Људи изражавају своју припадност једној култури или некој, није битно којој, групи прихватањем и афирмацијом њених кулинарских специфичности или прецизним дефинисањем различитости од других култура, што нам даје исти резултат. Уношењем нечега у себе, у организам (принцип инкорпорације) рађа се идентитет (постајемо оно чиме се хранимо), што је тачно и биолошки и имагинарно: црвена меса, пуна крви, наводно нам дају енергију; анемична репица ће ономе који је поједе дати адекватну енергију. Инкорпорација је фактор на основу којег се утемељује колективни идентитет и, истовремено, принцип промјенљивости. ${ }^{59}$ Утолико уношење одређене врсте хране јесте хабитус, „виђење света једне групе/класе”б0, који се носи

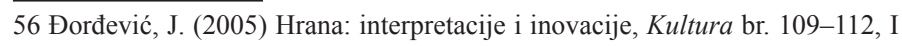
knjiga, Beograd: Zavod za proučavanje kulturnog razvitka, str. 41.

57 Исто, стр. 39-40.

58 Fišle, K. nav. delo, str. 181-198.

59 Исто, стр. 189-190: Фишле наводи неке примјере који доказују да један народ или једну групу дефинишемо на основу онога чиме се та група храни: за Французе, Италијани су „макаронџије”, Енглези су „розбифовци”, а Белгијанци „помфритџије”, за Енглезе, Французи су „жабари”, Американци називају Нијемце „купусарима”. Не само да онај који једе у себе уноси особине хране коју поједе, већ и узимање хране инкорпорира оног који једе у оквир одређеног кулинарског система, дакле у оквире одређене друштвене групе, или је из ње искључен уколико тај систем не постоји.

60 Golubović, Z. Doprinos Pjera Burdijea humanizaciji društvenih nauka, u: Nasleđe Pjera Burdijea: pouke i nadahnuća priredili Nemanjić, M. i 
са собом и изван мјеста становања. Хабитус је истовремено принцип „генерисања пракси” подложних објективном класирању и „систем класирања” (,principium divisionis”) тих пракси. ${ }^{61}$ Управо је однос између те двије способности које дефинишу хабитус - способност производње пракси и дјела подложних класирању и способност разликовања и оцјењивања тих пракси и дјела (укус) - оквир у којем се конституише „представљени друштвени свијет”, односно „простор стилова живота”. Ђурчани и њихови потомци и након 1991. године задржавају кулинарску традицију припремљеног заједничког јела за свечаност, што показује да група изражава и потврђује индивидуални и колективни идентитет и кроз исти јеловник и послије протјеривања из географије. На тај начин група потврђује свој хабитус.

Ако не знамо тачно чиме се хранимо, пита Фишле, није ли онда тешко сазнати не само и шта ћемо постати, већ и шта тренутно јесмо? Појединци који припадају једној култури имају кухињу међу осталим стварима која им помаже да се одреде и да се у њој препознају, а Ђурчани и њихови потомци се и даље према њој одређују и у њој препознају.

\section{Рецеепт за дебеле колаче}

Потребни су слиједећи састојци: герма, млијеко, брашно, шећер, со, уље, 1 јаје, маст. Ставити герму у 1 дл млаког млијека и оставити да герма крене. У ванглу усути 1 кг брашна, додати герму с млијеком и још мало млијека, па све узмијешати кувачом. Покрити ванглу кухињском крпом и оставити тијесто да докисне. У докиснуто тијесто ставити кашику шећера, мало соли, уља и 1 јаје. Мијесити додавајући млијеко по потреби колико треба брашну. Подијелити тијесто на два дијела и домијесити, па оставити и чекати мало да тијесто крене. У међувремену припремити самљевени мак или орахе и додати им шећер. Када тијесто докисне, развући га, посути зашећереним маком или орасима, мало замастити и завити у „лист”. Одозго сваки „лист” премазати машћу и оставити да стоји како би докиснуо. На крају „листове” ставити у крушну пећ и пећи. Испечене ,листове” попрскати водом, а охлађене исјећи на шните и сложити на тањир.

Spasić, I. (2006), Beograd: Institut za filozofiju i društvenu teoriju, Zavod za proučavanje kulturnog razvitka, str. 17-18.

61 Burdije, P. (2005) Habitus i prostor stilova života, Kultura br. 109-112, I knjiga, Beograd: Zavod za proučavanje kulturnog razvitka, str. 132. 


\section{БОРИСЛАВА ВУЧКОВИЋ}

\section{ЛИТЕРАТУРА:}

Bernstajn, B. (1979) Jezik i društvene klase, Beograd: BIGZ.

Burdije, P. (2005) Habitus i prostor stilova života, Kultura br. 109-112, I knjiga, Beograd: Zavod za proučavanje kulturnog razvitka, str. $131-170$.

Golubović, Z. Doprinos Pjera Burdijea humanizaciji društvenih nauka, u: Nasleđe Pjera Burdijea: pouke i nadahnuća priredili Nemanjić, M., Spasić, I. (2006), Beograd: Institut za filozofiju i društvenu teoriju, Zavod za proučavanje kulturnog razvitka, str. 13-23.

Gudi, Dž. (2005) Gore i dole: kulinarska kultura Azije i Evrope, Kultura br. 109-112, I knjiga, Beograd: Zavod za proučavanje kulturnog razvitka, str. $63-130$

Đorđević, J. (2005) Hrana: interpretacije i inovacije, Kultura br. 109-112, I knjiga, Beograd: Zavod za proučavanje kulturnog razvitka, str. $11-53$.

Исић, М. Приватност на селу, у: Приватни живот код Срба у двадесетом веку приредио Ристовић, М. (2007), Београд: Clio, стр. 379-407.

Јовановић, Б. Крсна слава, у: Приватни живот код Срба у деветнаестом веку: од краја осамнаестог века до почетка Првог светског рата приредили Столић, А. и Макуљевић, Н. (2006), Београд: Clio, стр. 593-607.

Костић, С. Ђ. Окрепљење тела, у: Приватни живот код Срба у деветнаестом веку: од краја осамнаестог века до почетка Првог светског рата приредили Столић, А. и Макуљевић, Н. (2006), Београд: Clio, стр. 385-402.

Minc, S. (2005) Hrana, društvenost i šećer, Kultura br. 109-112, I knjiga, Beograd: Zavod za proučavanje kulturnog razvitka, str. 287-301.

Prošić-Dvornić, M. (2005) Kulturni i društveni značaj hrane u tradicionalnoj srpskoj kulturi, Kultura бp. 109-112, II knjiga, Beograd: Zavod za proučavanje kulturnog razvitka, str. 315-336.

Prošić-Dvornić, M. (2006) Odevanje u Beogradu u XIX i početkom XX veka, Beograd: Stubovi kulture.

Тимотијевић, М. (2006) Рађање модерне приватности: приватни живот Срба у Хабзбурикој монархији од краја 17. до почетка 19. века, Београд: Clio.

Fišle, K. (2005) Funkcije ishrane, Kultura br. 109-112, I knjiga, Beograd: Zavod za proučavanje kulturnog razvitka, str.181-209.

Furnije, D. (2005) Fermenti kultura, Kultura br. 109-112, I knjiga, Beograd: Zavod za proučavanje kulturnog razvitka, str. 302-311.

Hobsbom, E. Uvod: kako se tradicije izmišljaju, u: Izmišljanje tradicije priredili Hobsbom, E., Rejndžer, T. (2002), Beograd: Biblioteka XX vek, str. 5-25. 


\title{
БОРИСЛАВА ВУЧКОВИЋ
}

Чолак-Антић, Т. Један кратак поглед у књигу рецепата, у: Приватни живот код Срба у двадесетом веку приредио Ристовић, М. (2007), Београд: Clio, стр. 362-376.

\section{Borislava Vučković \\ Belgrade}

\section{A FESTIVE DINNER}

\begin{abstract}
This study of a festive dinner in a rural micro-community in the period of socialist Yugoslavia shows how a group confirms and redefines its existence through a formal menu. The menu bears the male sex signifier, yet matches the taste of all the consumers. The abundance of meat in the meals shows that "a class body" - a strong (male) body is desirable, revealing the deepest dispositions of habitus. Alcoholic drinks are taken by both men and women, yet men drink more being members of a more dominant sex, thus having a greater need in reproducing the cultural norm. The activity of preparing and serving food at the table is not subject to ritual rules and bears the female sex signifier. By introducing changes in the menu and by emancipation of the woman at the dinner table, this patriarchal micro-community shows dynamics and flexibility, thereby negating the stereotype of the rural population as passive. The differences in the economic power are least visible at the festive dinner table, which confirms the Bourdieu's statement that food is a privileged field where it is symbolically possible to regain dignity and self-respect of the social groups positioned at the bottom of the social ladder, in real economic and social terms.
\end{abstract}

Key words: food, drink, festivity, rural micro-community 